


\section{An Ethical Concern on Gender-Based Violence against Women and Girls in Africa during COVID-19 Lockdown}

\section{Linus O. Akudolu \& Hillary O. Eze}

Email: oluchukwu1900@gmail.com

Department of Philosophy, Alex Ekwueme Federal University, Ndufu-Alike, Ikwo, Ebonyi State, Nigeria.

\section{Abstract}

Activists, journalists and the United Nations (UN) have drawn attention to the rising level of gender-based violence (GBV) against women and girls across the globe during the coronavirus pandemic. It is on this note that we undertake to look critically into the matter with a view of assessing the moral implications of such violence, with special attention to African nations. Adopting Kantian moral philosophy, which emphasizes that we should not treat human being as a means to an end but as an end itself, the paper condemns the actions of the culprits, and government responses both to the pandemic and reported cases of gender-based violence, without adequate attention to the plight of female folk. The paper also makes various recommendations and suggestions on how to handle such pandemic without keeping women and girls vulnerable to sexual based violence. Concerning the nature of the topic, a qualitative method of research is applied, using survey, phenomenology, critical analysis and review of library materials.

Key Words: Gender-Based Violence, COVID-19, Pandemic, Feminism, Gender Equality, Rape. 


\section{Introduction}

Gender-based violence (GBV) refers to all violent acts primarily or exclusively committed against a person specifically because of his or her gender. It can be against men or women, but greater numbers of gender based violence are meted against female folk. This has made many scholars to conceive and define it in favor of women and girls, calling it sexual and gender-based violence against women and girls (SGBV). It is in this vein that a gender scholar, Richters, defined it as all acts or threats of acts intended to hurt or make women suffer physically, sexually or psychologically, and which affect women because they are women or affect women disproportionately. ${ }^{1}$ Sexual and gender-based violence against women and girls (SGBV) are therefore all violent acts against female folk that result or likely to result in physical, sexual, psychological or economic harm or suffering, including threats of such acts, coercion or arbitrary deprivation of liberty, whether occurring in public or private life. Such violence is often seen as a form of hate crime committed against women or girls because of their gender, mostly perpetrated by men. 1993 Declaration on the Elimination of Violence against Women also revealed that such violence is rooted on gender inequality between men and women. It stated that "violence against women is a manifestation of historically unequal power relations between men and women and that violence against women is one of the crucial social mechanisms by which women are forced into a subordinate position compared with men". ${ }^{2}$ In similar view, the United Nations Development Fund for Women stated:

Violence against women and girls is a problem of pandemic proportions. At least one out of every three women around the world has been beaten, coerced into sex, or otherwise abused in her lifetime with the abuser usually someone known to her. ${ }^{3}$

There are various forms of gender-based violence against women and girls. It includes rape whether marital or extra marital type, domestic violence, honor killings, forced marriage, reproductive coercion, marital disappointment, divorce, denial of fundamental human rights like freedom of speech and movement, denial of inheritance rights, sexual harassment, human trafficking and forced prostitution, maltreatment of widows, forced sterilization and forced abortion, female genital mutilation, cyber-bullying and many others. 
The history of violence against women and girls is difficult to trace as it began in a time immemorial. It manifests in many ancient literatures even in the Bible where a woman is regarded as a rib from man, thereby taken to be a secondary human being. ${ }^{4}$ She is not allowed to speak in the public or enter into the inner parts of the sanctuary. She cannot perform priestly functions and is denied certain sensitive positions. In the book of Genesis Chapter 4, we have a story of a man called Lamech, who told his two wives how he killed a young man because he made him angry, and was threatening to kill them (his two wives) if they dare him. In his words: "Adah and Zilah, hear my voice, ye wives of Lamech, hearken unto my speech: for I have slain a man to my wounding and a young man for my hurt" $(G e n .4: 23)^{5}$. This implies that if they did not hearken to him, he would kill them. What a bully! This is exactly how many men bully their wives. The wives have no mouth, no right and no freedom.

The story in the Gospel of St. John about a woman caught in adultery is another Biblical evidence of women violence even in the time of Jesus Christ. ${ }^{6}$ According to the chapter, the scribe and Pharisees brought a woman to Jesus Christ, claiming that they caught her in the very act of adultery and were about to stone her in accordance to the Law of Moses. It was amazing that it was only the woman that was brought. Where is the man that was committing the adultery with her? The man was allowed to go his way but the woman was prosecuted. This is similar to what happens in our society especially in Africa where a man can leave his wife and cling to another woman. Some even bring their "side chicks' ' into their houses, inside their bedrooms, and on top of their marital beds and the wives have no right to talk. If she dares to raise her voice, she would be sent packing. The man can even bring in the "side chick" as his second wife and he would be celebrated, while his original wife remains in agony. I am very glad on how Jesus Christ handled the matter. He told all the men that had gathered to stone the accused woman "He that is without sin among you, let him first cast a stone at her" stooped down writing on the ground. Being convicted in their own consciences for they had committed similar sins, they left beginning from the eldest to the youngest.

Similar to the above scenario is a typical African society where men are regarded as human beings and women as objects to be possessed and handled anyhow by men. The underlying reason for this is because African society is patriarchal in nature, a male dominated environment, where men are seen as lords and women and girls as objects, to be subjugated and maltreated. Ikegbu, in his work ,"The Place of women in political Development" maintains that the potency of 
man and his position/place in a given society is incontestable in the African context with that of a woman. He stated thus:

It is trite rule that family which is the beginning of existence in Africa is hierarchically structured which ultimately places man as the head of the family confers him the right to initiate and implement policies in its nuclear character or polygamous family structure. ${ }^{8}$

What he tried to express here is that man in Africa, has his place as the head of the family and reserves the right to run the family as he pleases. The same right is also transferred to a male child, such that in the absence of the father, the male child is preferred to make decisions instead of the mother or the older female children.

Africans indulge in a high level of injustice in this belief. It is worth noting that the most dominant and persistent aspect of the patriarchal thought pattern is the belief in male superiority and female inferiority. As a result, a woman is rarely involved or given a chance to give her opinion on matters or decision making in family and society. ${ }^{9}$ Because of the poor conception about women in African society, gender inequality and gender-based violence are very high in the society. The violence really increased in Africa during the COVID-19 pandemic than it used to be. It is on this note that this article shares insights, ethical implications and suggestions on violence against women and girls (VAWG) in several African countries during the pandemic. The ethical framework adopted is the Kantian moral philosophy, and the method used in this study is a qualitative method of research.

\section{COVID-19 and the Spike of Gender-Based Violence in Africa}

Coronavirus started in Wuhan in China in November 2019, and spread in an unprecedented manner across the globe. Various governments of the world enforced lockdown policy, restriction of movement, ban on public gathering, frequent washing of hands with running water, use of sanitizer and wearing of facemask in order to checkmate it. These policies, though assumed to be helpful in controlling the spread of the virus, led to global upsurge in gender-based violence (GBV) against women and girls. The situation in Europe was well highlighted, indicating greater upsurge in gender based violence against women and girls (VAWG) in China, Spain and France, though Africa was not exempted. Liberia, Kenya, Uganda, Nigeria, and Côte d'Ivoire are notable African countries with so many reports on such violence since the beginning of the pandemic. Kenya and 
Nigeria has an average increase of SGBV of 30-50 percent since lockdown was enforced..$^{10}$ This is an indication that states' responses to COVID-19 contribute to the upsurge. However, various reports from South Africa, Canada and a multi-country analysis by The Washington Post show there was insignificant change in the reporting rates before and during the lockdown. ${ }^{11}$ Therefore, the increase in

SGBV during pandemic cannot be associated with increase in the reporting rates, but indicates there was significant upsurge in gender related violence during the lockdown. ${ }^{12}$ The use of social media such as Facebook and WhatsApp had been very helpful during the lockdown as it gave people avenues to let their voices heard. Most gender-based violence reported include rape, sexual harassment, home violence and physical assault both from family members and relatives, members of the public and law enforcements agents.

Let us just cite some of the notable and confirmed reported cases. One night in May, 2020, in Ghana, Victus Kuudiyiri, attacked her wife, with an axe, and had her face slashed and her skull cracked, simply because she denied him sex. ${ }^{13}$ A friend's neighbor poured hot soup on her, affecting her ears that she could no longer hear, and her body "painted" with scars from frequent beatings. ${ }^{14}$ In Benin Republic, a woman trader reported how her husband, who lost his job after his workplace was closed down as a result of the lockdown, beat her constantly. ${ }^{15}$ There was also a report about a Nigerian man who beat his wife severely and dared the police to arrest him by posting her bloodied body to social media. ${ }^{16}$ The stories are numerous. It is more than home violence. In March in Ugandan, police whipped female traders and hawkers who were selling their goods and wares at the lockdown. ${ }^{17}$ Some weeks later, five soldiers were arrested in Rwanda for raping women and girls in a Kigali slum while enforcing the lockdown order in the country. ${ }^{8}$ In April, 2020, three police officers beat a woman, Halima Abdulazeez, as she walked to a close-by community pharmacy to buy medicines for her sick child. ${ }^{19}$ Also in the same April, 2020, in Strandfontein, South Africa, a man was accused of raping a young woman at a temporary shelter for homeless people during the lockdown. ${ }^{20}$ In Nigeria, there were countless reports of rape even done against little girls and infants. The reason may be because the lockdown did not give men opportunities to meet their "side chicks". Students were also no longer in school and many male students who used to have "campus wives" could no longer control their orgies, and resorted to rape. 
In the foregoing scenarios, the link between SGBV and Covid-19 lockdown cannot be skeptical. An April 2020 report by the Center for Global Development on pathways to violence during the lockdown attempts to adduce various reasons that seem credible regardless of context: they include the economic strain of lockdown policy; social isolation which limited many from regular access to social outlets, and exploitative relationships; and reduced access to sources of support. ${ }^{21}$ However, these reasons can neither explain the causes of violence that were already occurring before the pandemic nor violence by security personnel against civilian women. Such prior violence can be attributed to underlying cultural norms and social inequities in our society that make gender violence a sundry affair. More so, these explanations do not explain multilayered factors that make people resort to violence, rather, they are mere reflections on social and structural reasons for spike in gender related violence against women and girls during COVID-19, especially at the lockdown.

\section{Ethical Assessment and Reflections}

Is there justification for such sexual and gender-based violence during the lockdown? Are the responses of the government to the pandemic justified vis-à-vis the fate of women and girls? Women and girls who were victims of GBV are human beings. In making any policy, decision or action, the actors must consider the place of man in the universe. Man is at the center of the universe. He is more valuable than any other thing. He must be treated as an end itself not as a means to an end. This is the stand of Immanuel Kant in his moral philosophy.

The German philosopher, Immanuel Kant (1724-1804) was an opponent of utilitarianism. Kant, unlike Mill, believed that certain actions (including murder, theft, and lying) were absolutely prohibited, even in cases where the action would bring maximum happiness than the alternative. The consequence of an action does not make it good but how man is treated. He believed that man is a rational being endowed with reasoning, freedom and choice and his interest must be given priority.

According to him, there are three questions we must ask ourselves whenever we want to make decisions and these he called three categorical imperatives: (i) Can I rationally will that everyone will act as I propose to act? If the answer is no, then we have to refrain from performing the action. In his words, "Act only according 
to that maxim by which you can at the same time will it become a universal law". ${ }^{22}$ In other

words, what would be the order of the day if every other persons act as I do? This question applies potently to the perpetrators of GBV against women and girls. Automatically, if the GBV is legalized and becomes a universal maxim, some of the perpetrators would become victims in one way or the other. They may be raped by a HIV gay rapist, or their wives and daughters raped. They may be maltreated by someone more powerful than them, and they would understand what their victims pass through. Considering these, we believe that none of those cruel men would accept their actions to be a universal law. Government officials are mostly men. If they consider the effect of GBV on the victims or place themselves in their shoes, they must put actions in place to checkmate it.

This is not the first time we have pandemic in Africa with an upsurge in gender-based violence, and we ought to have learned our lessons but failed because of "it doesn't concern me attitude" by the government. We can recall that during the Ebola crisis in 2015, outbreaks of varied gendered violence accompanied the virus's spread across East and West Africa. Experts have documented correlations between Ebola and rises in violence against women in Guinea, Liberia, and Sierra Leone. In Sierra Leone, teenage girls were the worst affected by sexual abuse in quarantined homes and as they sought food to survive, resulting in a teenage pregnancy epidemic. In the Democratic Republic of the Congo (DRC), some health workers reportedly asked infected women and girls for sex in exchange for treatment. If we are reliving this dark past today, we clearly have not learned our lessons well. But the fact remains that the government treats this issue with levity, and "it doesn't concern me attitude". This is very bad and unethical practice and attitude.

Kant's second categorical imperative states, "Act in such a way that you treat humanity, whether in your own person or in the person of another, always at the same time as an end and never simply as a means". ${ }^{23}$ Kant argues that rational beings can never be treated merely as means to ends; they must always also be treated as ends themselves, requiring that their own reason and motives must be equally respected. This is because man is a rational agent, all rational agents rationally will themselves to be treated with respect as end, and never as mere means to an end, never as objects, and never as tools. When a woman is raped, 
she is used as a mere object of sexual satisfaction. When the government makes policy without considering its cruelty or how to manage the cruelty, they use human beings as means to achieve their goals and not as ends themselves. Sexual and gender-based violence reduces the victims to mere objects and tools, and this has lots of negative effects on the victims' psych, health, and social well-being. It is unethical and must be dealt with.

His third categorical imperative, which is an inference from the first and second, stating: "Always act that the will could regard itself at the same time as making universal law through its maxim"24. To these, he adds: "A rational being must always regard himself as giving laws either as a member or as sovereign in a kingdom of ends which is rendered possible by the freedom of will" 25. This formulation requires that actions be considered as if their maxim is to provide a law for a hypothetical kingdom of ends. Accordingly, people have an obligation to act upon principles that a community would accept as laws. In such a community, each individual would only accept maxims that can govern every member of the community without treating any member merely as a means to an end. Although in the kingdom of ends, actions with good intentions sometimes result in harm, yet we are required to act categorically. In this sense, governments imposed lockdown with good intentions, which turned out to be bad as hunger and gender-based violence increased. They did not act categorically for not ensuring that palliatives were given to citizens, rather they embezzled the fund meant for the project. Out of hunger, people insisted on going out against the law, exposing many of them especially women and girls to various forms of violence. In addition, many African states were gender blind as they provided no avenue to hear the voice of victims of GBV during the pandemic and closed all the organizations both governmental and non-governmental organizations that can serve as support to the abused women and girls.

\section{Recommendations and Conclusion}

From the foregone, it is obvious that gender-based violence is morally wrong. It reduces women to the level of mere objects; instead of being treated as human beings, they are treated as tools. The perpetrators must desist from it. Government must no longer turn blind eyes and deaf ears to it whether in a pandemic or sundry period. They must take proactive measures against it. In other to achieve this, we recommend: 
1.Massive campaign and sensitization of the masses on gender-based violence: This includes enlightening the public on the dangers and consequences of such violence as well as raising their consciousness and consciences against it, through mass media, schools and various social gatherings. Similarly, many women do not know their rights and existing laws that protect them, and should be enlightened on this aspect.

2. Criminalization of all forms of SGBV: Lack of criminalization in many places, especially acts of abuse such as female genital mutilation, marital rape, forced marriage, child marriage and home violence are not criminalized. Those that are criminalized are often regarded as family matters or minor offenses and are not enforced. Therefore, all forms of GBV should be taken seriously both by government and security agents.

3. Formulation of Special Squad on Gender Matters: The attitude of police in many African countries towards the report of gender violence is very discouraging. They are often hostile to victimized women, and these women are prevented from obtaining justice. Recognizing these problems, some countries like Brazil, India and many others have enacted women's police stations, which are police stations that specialized in certain crimes, such as sexual violence, harassment, domestic violence committed against women.

4. Special Tribunal on Gender Matters: This needs to be set up as there is so much delay in obtaining justice in courts in Africa.

5. Provision of Palliatives and Welfare Schemes: Proper provision and distribution of palliatives to the masses especially to women should be carried out by African countries to ensure that the lockdown is observed. Without such provision, obedience to such laws is illusory. Some women were raped and others abused by law enforcement agents because they could not obey such order due to hunger and other basic needs.

6. Active Ministry of Women affair and Agencies: There must be active ministries and agencies that are charged with the responsibility of women issues. These should never be closed up even at lockdown and emergencies. As long as the world remains, there must be emergencies, and government should do the needful to ensure that the interests of the female folk are protected in such a period. 
Phone contacts to be called upon by the abused women during emergencies like pandemic should be made public.

7. Dealing with Deviant Officers: Deviant law enforcement agents should be dismissed and called to book.

\section{Conclusion}

In conclusion, gender-based violence which is also called sexual and gender based violence are actions done against any person due to his or her gender. It can be against men or women, but due to the patriarch nature of African society, women are mostly victims. Cases of such violence increased in Africa during the lockdown enforced as a result of coronavirus. We cited some of the notable instances and condemned the actions using Kantian moral philosophy. We have equally made some recommendations on how to control the social problem at sundry and emergency periods like pandemic. This paper therefore upholds the statement of koffi Annan on gender-based violence:

Such violence is unacceptable, whether perpetrated by the state and its agents or by family members or strangers, in the public or private sphere, in peacetime or in times of conflict... as long as violence against women continues, we cannot claim to be making real progress towards equality, development and peace" 26 


\section{References}

1. Richters, J.M. Annenire, Women, Culture and Violence: A Development, Health and Human rights Issue. Leiden, The Netherlands: Women and Autonomy (VENA), Leiden University, 1994.

2. UN, 48/104 "Declaration on the Elimination of Violence against Women". UN Resolution Adopted by the General Assembly, December 20, 1993. www.un-documents.net . Retrieved on October 10, 2020.

3. Moradian, Azad, "Domestic Violence against Single and Married Women in Iranian Society". Tolerance International. www.web.archieve.org, citing Annan, Koffi, "Facts and Figures on Violence against Women - say no to violence against women", 2008. In United Nations Development Fund for Women (UNIFEM). www.unifem.org/campaigns/vaw/facts-figure.php. Retrieved on July 28, 2009.

4. Genesis 2:21

5. Genesis 4:23 KJV

6. John 8:1-11

7. John 8:7

8. Ikegbu, E. A. The Place of Women in Political Development in Nigeria Citizenship Education 2nd edition. Ed. G. O. Ozumba et al Aba: AAU Vitalis Book Co, 2012, p.5.

9. Amadiume, Ifi. Male Daughters, female Husband: Gender and sex in African society. London: Zed books Ltd., 1987.

10. Ajayi, Titilope, "Violence against Women and Girls in the Shadow of COVID-19: Insights from Africa" Kujenga Amani, Social Science Research Council. www.kujenga-amani.ssrc.org. Retrieved on October 10, 2020

11. Htun, Mala and Jensenius, Francesca R., "The new Media's Reporting on Pandemic Spike on Violence against Women". Analysis, The Washington Post: Democracy Dies in Darkness, April 24, 2020. www.washingtonpost.com. Retrieved on October 10, 2020

12. Ajayi, Op.Cit. 
13. Mordey, Emmanuel K, "Man attacks wife with axe for denying him sex". News, Graphic Online, May 9,2020. www.graphic.com. Retrieved on October 10, 2020

14. Ajayi, Op.Cit.

15. Olivia, Aubierge H.K., "COVID-19: Costly Crisis for Women in Benin Republic" Institute for African Women in Law, April 20, 2020. www.africanwomeninlaw.com. Retrieved on October 10, 2020

16. Oja, Yetunde Ayobami, "Police arraign man who beat wife, posted photo online" Metro News, Guardian Newspaper. May 16, 2020. www.guardian.ng. Retrieved on October 10, 2020.

17. African Feminism, "How Uganda's COVID-19 Response Measures Are Failing Women". African Feminism, April 9, 2020. https://africanfeminism.com Retrieved on October 10, 2020.

18. Mensah, Kent, "Rwanda's soldiers rape women to enforce coronavirus lockdown". Article, Face to Face Africa, April 5, 2020.

https://face2faceafrica.com/articles. Retrieved on October 10, 2020.

19. Vanguard, "Nigeria security personnel flog woman in public" Video Clip, VanguardNewspaper, April, 2020.

https://www.vanguard.com/wp-content/uploadfs/2020/securitypersonnel.mp.4

Retrieved on October 10, 2020.

20. Staff Writer, "Man, 36, accused of Strandtontein shelter rape gets R2000 bail". News, Cape Time, April, 2020. https://www.lol.co.29/capetimes/news. Retrieved on October 10, 2020

21. O'Donnel, Megan et al , Gender Lens on COVID-19 Pandemics and Violence against Women and Childres". Center for Global Development, April 3, 2020. www.cgdev.org/blog/. Retrieved on October 10, 2020

22. Kant, Immanuel, Grounding for Metaphysics, $3^{\text {rd }}$ edition, trans. James W. Elington. Indianapoli/Cambridge: Hackett Publishing Company Inc., 1993, p.30.

23. Ibid., p.36

24. Ibid., p.43 
25. Stumpf, Enoch Samuel, Philosophy: History and Problem. USA: McGraw-Hill, Inc., 1994, p.318, rephrasing Ibid.

26. UN, "Annan calls for more political will to combat scourge of violence against women", UN News, October 9, 2006. www.news.un.org. Retrieved on October 10, 2020

\section{About the Authors}

Dr. Linus O.Akudolu and Dr. Hilary Eze lecture at Department of Philosophy, Alex Ekwueme Federal University, Ndufu-Alike, Ikwo, Ebonyi State. Each of them has a PhD in Philosophy, and they are married with children. 